\title{
Zionism and Pentecostalism: Black Zionist Roots in the AFM of SA through the Lens of Decoloniality
}

\author{
Mookgo Solomon Kgatle \\ https://orcid.org/0000-0002-9556-6597 \\ University of South Africa \\ kgatls@unisa.ac.za
}

\begin{abstract}
Contrary to literature that recognises American missionaries John G Lake and Thomas Hezmalhalch as cofounders of the Apostolic Faith Mission (AFM) of South Africa, this article seeks to demonstrate the role played by the Black Zionist movement in preparing the foundation of the AFM of South Africa. This shall be done by demonstrating the role played by Wakkerstroom Congregation; the Central Tabernacle in Zion; the distinctiveness of the Black Zionist movement; and the distinct Black Zionist leaders in South Africa. I argue through the lens of decoloniality that there was already a group of Black Zionists fellowshipping at what is known as Wakkerstroom Congregation when John G Lake and Thomas Hezmalhalch arrived in South Africa. This congregation later gave birth to the AFM of South Africa in 1908 and other Zionist churches thereafter. The Black Zionist roots of the AFM discussed in this article have three implications. First, they suggest that the AFM is truly a Black and African church; hence, the church grows largely among Black people. Second, these roots are important for sustaining the growth of the AFM in the future. Last, the discussion challenges church historians to consider the Black Zionist roots when studying the foundation of the AFM.
\end{abstract}

Keywords: Black Zionist roots; Apostolic Faith Mission (AFM); Zionism;

Pentecostalism; decoloniality 


\section{Introduction}

The majority of historians interested in the foundations of the Apostolic Faith Mission (hereafter AFM) recognise the American missionaries, John G Lake ${ }^{1}$ and Thomas Hezmalhalch as cofounders of the AFM of South Africa (Burger 1987, 42; De Wet 1989, 28; Erasmus 1996, 1; Hwata 2005, 97; Lindsay 1952, 3; Morton 2017, 13; Nicol 1966, 170; Reddy 1992, 31). However, other scholars, such as Sundkler (1976) and Oosthuizen (2000), emphasise the centrality of African converts in Wakkerstroom in the spread of Zionism and the early AFM, the largest classical Pentecostal church in South Africa. This view is also supported by Anderson (2000; cf. Anderson 1995) in his book, Zion and Pentecost: The Spirituality and Experience of Pentecostal and Zionist/Apostolic Churches in South Africa, having explored the relationship between Zionism and Pentecostalism. What is new in this present article, is the connection between these African roots and current discourses on decoloniality. In other words, the article seeks to explore the implications of the African roots in the AFM. Hence, this article uses decoloniality as the lens that moves away from colonial powers, thrives for transformation and recognises African contexts (see Hadebe 2017; Mashau 2018; Naidoo 2016; Ndlovu-Gatsheni 2017; Ramantswana 2016; Sakupapa 2018). Through this lens, I argue that the Black Zionist movement prepared the foundation for the AFM in South Africa. According to Mofokeng $(2018,2)$, "Literature on the AFM, written by both insiders and outsiders, hints at this possibility, but shies away from explicitly identifying the past of Black Pentecostalism as having been Zionist." One of the scholars who shy away from the debate is Matthew Clark $(2005,150)$, who calls the Black Zionist roots in the AFM "fictitious." However, Anderson (1995, 284) explains that these roots are important and that it is not easy to wish them away.

This article does not shy away from this pertinent discourse but seeks to demonstrate the Black Zionist roots in the AFM of South Africa and the implications thereof for decoloniality. The article has seven sections. In the first section, I seek to introduce different categories of Zionist churches and their link to Pentecostalism. In the second section, the South African Zionist movement is discussed as a distinct movement from other Zionist movements in other parts of the world. The third section points to the early Black Zionist leaders who also played a role within the Zionist movement in South Africa. In the fourth section, I highlight the influence of Wakkerstroom Congregation as one of the role players in preparing the foundation of the AFM and other Zionist churches in South Africa. Similarly, the fifth section recognises the role of the Central Tabernacle in Zion as the place of fellowship, prior to the acquisition of the church building by the AFM. The sixth section will illustrate the implications of links between

1 John G Lake was born in 1870 and died in 1935. He was a Canadian-American who came to South Africa as a missionary to minister the gospel together with Thomas Hezmalhalch (Morton 2012). John $\mathrm{G}$ Lake was known for the ministry of divine healing and the performance of other miracles. Many scholars recognise him as the co-founder of the AFM of South Africa. However, in this article it is argued that the Black Zionist movement in South Africa prepared the ground for the foundation of the AFM. 
Zionism in South Africa and the AFM, which is the main argument for the Black Zionist roots in the AFM. Last, I discuss three implications of the Black Zionist roots of the AFM for church historians interested in the history of the AFM and South African Pentecostalism.

\section{Zionist Churches and Pentecostalism in South Africa}

The Zionist churches, according to Anderson $(2001,108)$, are "the southern African equivalent of the continental terms prophet-healing and spiritual." These churches are defined by West (1975) in Anderson $(2001,108)$ as "Pentecostal, apostolic movement, stressing the influence of the Holy Spirit and of divine healing, and combining both African and European cultural elements." Anderson $(1991,1)$ has combined the term Zionist and Apostolic into one category encompassing the Zionist churches in South Africa. However, there could be other categories, as Anderson $(1991,2)$ notes that "many independent churches in southern Africa would prefer not to be associated with the term 'Zionist' - even though they may well fit into a 'Zionist-type' category." In his other article, Anderson (1999b, 312) discusses Zionist and Apostolic together as churches that recognise healing and prophecy more on a personal level (cf. Ramantswana 2019, 4). The Zionist-type churches, like many Pentecostal churches, emphasise the work of the Holy Spirit in the believer in healing and prophecy (Sundkler 1961, 242). Hence, Hollenweger $(1972,151)$ in Anderson and Otwang $(1993,3)$ refers to all of the above-mentioned categories of Zionism as "independent African Pentecostal churches."

What many scholars have failed to do, is to draw a distinction between the prophetic office in African Traditional Religion (ATR) ${ }^{2}$ and Zionism. Some, for example according to Anderson and Otwang $(1993,122)$, have confused the prophetic office in Zionism with divination in ATRs. However, Anderson and Otwang $(1993,130)$ clarify: "To say that the Zionist prophets have simply taken over the function of the traditional diviner is to miss the point." Other reasons for dismissing and demonising Zionism, according to Anderson $(2005,69)$, is "their wearing distinctive church apparel and their symbolic healing practices, which White Pentecostals saw as unscriptural." In my own opinion, it is because of these reasons highlighted by Anderson and Otwang that many scholars are quick to dismiss the Black Zionist roots in the AFM of South Africa.

\section{The Distinctiveness of the Black Zionist Movement in South Africa}

The Black Zionist movement in South Africa has some similarities with other movements elsewhere in the world. Sundkler $(1976,34)$ mentions the influence of John

2 African Traditional Religions are religious groups in the continent that are centred on traditional and cultural beliefs rather than scriptural beliefs as in other religions like Christianity. 
Alexander Dowie ${ }^{3}$ and Daniel Bryant ${ }^{4}$ in South African Zionism. Nel $(2020,11)$ also relates the Zionist churches in South Africa to Dowie. However, other scholars have come to recognise their distinction from such movements. One such scholar is Etherington $(1979,125)$, who says that although the Zionist movement in South Africa has followed the general name used by the Americans, for example, they have, however, demonstrated unique indigenous features since their foundation. The point by Etherington suggests that most of the Zionist churches in South Africa are fundamentally based on the African culture, but with strong biblical principles and beliefs. Khorommbi $(2001,20)$ concurs: "Although the beginnings of the African Zionist movement have some links with Dowie's movement and White members, the actual African Zionist groups of churches have always been founded by Africans themselves since then." In addition, according to De Wet $(1989,35)$, the capable indigenous leadership led most of these Zionist churches. In the next section, I will point to some key Black Zionist leaders prior to the foundation of the AFM in South Africa.

It must be reiterated that the Black Zionist churches maintained the core practices of Zionism, similar to Pentecostalism, like the role of the Holy Spirit in prophecy and healing. In addition, according to Oosthuizen (2000, 1101) they are known for "purification rites and taboos as the main means of expression of their faith." As noted in the preceding section, these rites have made many Pentecostals to dismiss them within their ranks. Ranger $(2007,65)$ points out that these types of churches have gained independence from the manipulation of missionaries, many of whom have used the Bible to undermine African culture. Most of these churches broke away from the missional churches that oppressed the majority of Black people in South Africa. Khathide $(2010,46)$ adds that as religion could not be expressed freely in an African way through many denominations led by Western missionaries, the Zionist churches became an option to move away from White control during apartheid.

\section{Distinct early Black Zionist Leaders}

Some important early Black Zionist leaders of the Zionist movement included Daniel Nkonyane, Paul Mabilitsa, Elias Mahlangu, Titus Msibi, Edward Motaung and Engenas Lekganyane (Khorommbi 2001, 20; cf. Moripe 1996, xiv). Daniel Nkonyane had been

3 John Alexander Dowie was born in 1847 and died 1907. He was of mixed Scottish and Australian descent. He founded the Christian Catholic Apostolic Church in 1896, with its headquarters at Zion City, near Chicago. "Zion" was a theocracy and Dowie regarded himself as a first Apostle of Jesus Christ, but later as "Elijah the Restorer." Divine healing — without doctors or medication —was one of the tenets of his church, together with a number of taboos. Thus, Dowie became known as a practitioner of divine healing throughout his ministry (Sundkler 1976, 30; cf. Kgatle 2016c, 163).

4 Dowie desired to start working in South Africa but he could not come himself. Therefore, he delegated Daniel Bryant to come and represent him in South Africa. Bryant, together with his wife, was a committed man in the work of ministry, who gave his life to the cause of Zionism for about four years. However, when news broke about the fall of Dowie, the couple returned to the United States (Sundkler 1976, 34; cf. Kgatle 2016c, 166). 
with Pieter Le Roux ${ }^{5}$ ever since the latter's Dutch Reformed days in the 1890s and was himself originally a member of the Dutch Reformed mission. Nkonyane and his wife shared Le Roux's experiences. When Nkonyane was dismissed as a leader, he founded the Christian Catholic Apostolic Holy Spirit Church in Zion (Kgatle 2016b, 3; cf. Morton 2014, 29). In addition, Nkonyane was a resident of Wakkerstroom that I discuss in the next section as the centre of Zionist meetings. Elias Mahlangu was also an associate of Le Roux and was once appointed an overseer by the same (see Morton 2017, 10). Engenas Lekganyane was influenced by Edward Motaung, one of the Zionist leaders, who worked in Basutoland under his Zion Apostolic Faith Mission; hence, one of Engenas's sons was named Edward, after Motaung. However, after parting ways with Motaung, he moved to Thabakgone, Boyne, Moria in Polokwane to start the Zion Christian Church $^{6}$ (ZCC) (Morton 2014).

\section{The Influence of Wakkerstroom Congregation}

Most of the Pentecostal churches, including the African Initiated Churches (AICs) like the ZCC mentioned above, have their roots in the Zionist movement that emanated from Wakkerstroom Congregation located in the province of Mpumalanga, South Africa (Poewe 1988, 148). The history of Wakkerstroom Congregation and Zionism can be understood in light of the people who seceded from the Dutch Reformed Church (DRC) together with Pieter le Roux, a DRC missionary. This group of about 150 people, including co-workers and converts, left the DRC to join the Zionist movement in South Africa in 1902 (Dowie 1904; Le Roux 1913, 2; cf. Anderson 1999a, 90). From that small number of people, Wakkerstroom Congregation grew to thousands by 1905 and became the mother body for many other Zionist-type and AICs churches at that time (Kgatle $2019,6)$. According to Roy $(2000,120)$, this congregation gave birth to many leaders of the Zionist churches, such that it can be called the "Jerusalem" of the Zionists in South Africa. Anderson (1992, 21), as quoted in Daneel (2004, 200), concurs: "Wakkerstroom was to the South African Pentecostal-type churches [Zionist churches] what Azusa Street was to the world-wide Pentecostal movement." Thus, scholars recognise this congregation as the nucleus of the Zionist movement, but also with an influence on Pentecostal churches like the AFM.

5 Pieter le Roux was born in 1965 and died in 1943. He was a missionary in the Dutch Reformed Church but later resigned to join the South African Zionist movement in Wakkerstroom to work with many Black converts and leaders. He joined John G Lake and Thomas Hezmalhalch in the Central Tabernacle in Zion with some of the Black Zionist members who later became members of the Apostolic Faith Mission of South Africa. Le Roux was one of the influential leaders in the AFM who became the president after the departure of John G Lake (see Nel 2005).

6 Zion Christian Church (ZCC) is one of the largest African Initiated Churches (AICs) in the region of southern Africa (that was founded by Engenas Lekganyane) and its headquarters are in the province of Limpopo (Lukhaimane 1980; cf. Anderson 2013). Today, ZCC has a large membership, estimated between 8 to 10 million. and its main pilgrimage hosted annually during Easter is also attended by thousands of people. The church cancelled their 2020 Easter pilgrimage in favour of the safety of their members in light of Covid-19. 


\section{The Role of the Central Tabernacle in Zion}

The ministry services by John G Lake and Thomas Hezmalhalch were initially held in a small Zionist church in Doornfontein, Johannesburg. However, as these meetings attracted many people, the area became small for a large crowd of people to assemble in Doornfontein. It was during this period that the meetings were moved to the Central Tabernacle in Zion, which belonged to the Zionist movement in South Africa. According to Maxwell $(1999,246)$, most of the Zionist members automatically became members of the AFM of South Africa. Eventually, the Central Tabernacle of Zion, the Tabernacle in Bree Street, South Africa, became the central place for the AFM of South Africa (Roy 2000, 121; cf. Burger and Nel 2008, 72). According to Erasmus (1996, 39), the Central Tabernacle became the mother assembly of the AFM between 1908 and 1914, where the president of the AFM, John G Lake, became the local pastor with Thomas Hezmalhalch as co-pastor. According to Hwata (2005, 22), Hezmalhalch initially became the chairperson because of his age, but soon John G Lake took over as Hezmalhalch had left the country.

According to De Wet $(1989,54)$, the services held in the Central Tabernacle were instrumental in drawing the crowds to the AFM, as many people who attended the services came back with testimonies. Hwata $(2005,23)$ adds that most congregants coming out of this assembly became instrumental in planting various AFM assemblies throughout the country, spreading the message of baptism in the Holy Spirit and the evidence of speaking in tongues. The Pentecostal experiences of spirit baptism, speaking in tongues, and other signs in this assembly were similar to the experiences in the Azusa Street Revival (Kgatle 2016a, 330). Resane (2018) adds that the healing ministry in these meetings became the major draw card to attract the people to the assembly. However, it must be noted that it was in the same assembly that the AFM, according to Horn (1991), determined separate services for the White, Coloured, Indians and Black people. It was the declaring of these sections, the Black, White, Indian and Coloured (see Kgatle 2017, 3), that alienated many Zionist members from the AFM, causing multiple schisms where many started their own churches (Kgatle 2016b).

\section{Black Zionist Roots of the Apostolic Faith Mission of South Africa}

There is a link between Zionism and Pentecostalism demonstrated by the Black Zionist roots in the AFM of South Africa (Sundkler 1961, 200; cf. Anderson 1999b, 286). According to De Wet $(1989,25)$, the Pentecostal movement in South Africa is a product of the Zionist movement at the turn of the 20th century. Anderson $(1999 \mathrm{~b}, 286)$ points out: "In the earliest stages, it was not possible to separate South African Pentecostalism from the Zionist movement, as each borrowed extensively from the other, if they did not always regard their movements as identical, they were certainly complementary." Reddy $(1992,9)$ reiterates: "The early Zionist congregations formed the nucleus of the Pentecostal movement and later the Apostolic Faith Mission of SA (AFM)." Mofokeng $(2018,2)$ recently contended that among Black Pentecostals, the AFM-although regarded as evangelical — has Zionist roots. Mofokeng and Madise (2019, 2) add: 
"Black Pentecostalism in the AFM showed remarkable theological and phenomenological similarity to the developing independent Black Zionist movement until the 1950s and 1960s."

The Black Zionist roots in the AFM are illustrated in three ways. First, the practice of baptism through triple immersion and the emphasis on divine healing in Zionism became the same practices in the AFM. This is a unique practice, according to De Wet $(1989,37)$, as many Pentecostals around the world use single immersion. Second, both Wakkerstroom Congregation and the Central Tabernacle in Zion became instrumental in launching the AFM of South Africa, with the latter becoming the headquarters of the church officially in 1908 . Mofokeng $(2018,41)$ calls these two congregations epicentres of both Zionism and Pentecostalism in South Africa. Third, most Black members of the Zionist churches became members of the AFM of South Africa (Burger and Nel 2008, 27; De Wet 1989, 37; cf. Hollenweger 1972, 120). Moreover, in the early years, the relationship between Zionism and Pentecostalism was continuous, such that it was not possible to separate the two movements. According to Anderson $(1996,147)$, most of the Zionists retained their roots but added some of the Pentecostal beliefs without compromising their own beliefs (Anderson 1996, 147). Anderson (1999b, 285) adds: "Both Zionists and Pentecostals preach deliverance from sickness and the oppression of evil spirits, and especially a message receiving the Holy Spirit." Thus, it can be concluded that the Zionist movement in South Africa paved the way for the Pentecostal movement in South Africa through the AFM (Maxwell 1999, 246).

\section{Implications of the Black Zionist Roots of the AFM}

\section{AFM as truly a Black and African Church}

Black Zionist roots of the AFM suggest that the church is truly a Black church that grows largely among Black people (Richardson 2013, 44). Most AFM churches in South Africa and the diaspora have Black people as the majority of their members. The Black Zionist roots of the AFM do not dismiss entirely the contribution made by John G Lake and Thomas Hezmalhalch in preaching the gospel in South Africa. Besides, the duo are products of a Zionist movement as well. However, Lake and Hezmalhalch were able to start the AFM because the Zionist movement in South Africa had prepared the environment to be conducive and possible for a revival to happen in South Africa. The contribution of the Zionist movement does not only relate to doctrinal issues like baptism in triple emersion and the practice of divine healing, it is also a contribution in terms of resources, like the Central Tabernacle in Zion, as highlighted in preceding sections. Therefore, the AFM is genuinely an African church with her roots in Africa because Africans prepared the way for the church to be founded in South Africa. Although the name has a similarity to the Apostolic Faith of William Seymour in the Azusa Street Revival, Los Angeles, in the United States of America, it does not make AFM an American church. 


\section{The Future of the AFM}

The future of the AFM as a Black and African church located in South Africa depends on the recognition of its roots. Although it is not necessarily wrong to continue to recognise and celebrate John G Lake, this should be done in congruency with the recognition of the Zionist movement in South Africa. In my view, these roots have made the AFM of South Africa a stronger Pentecostal church in Africa with branches all over the continent. The church has even spread to other continents outside Africa since the departure of John G Lake and his entourage went back to America. However, for the church to continue to make an impact among its people, there is a need to recognise the roots that made it to be where it is today. There is a need, according to Tshaka (2015, 3 ), to take the "lived experiences of Black people seriously." Unfortunately, the AFM has moved away from its Zionist roots towards evangelicalisation, mostly to please the interest of the White membership (Mofokeng 2018, 1). However, there is no need for the AFM to yield to pressure to adjust to the Western ways of running the church; rather, it should remain relevant and accessible to African people. The AFM (in order to remain relevant even for future generations) should recognise its clientele and render services to them. It is through these endeavours that the AFM will remain an influential church in Africa, but that cannot happen unless there is full recognition of her Black Zionist roots. According to Erasmus $(1996,34)$, had the AFM agreed to add Zion to their name, the church would have grown in status:

If the AFM had been able to maintain their ties with the "Zion" Pentecostal wing in Africa, the AFM would most probably by now have been the biggest, most effective and most influential church in southern Africa.

\section{The Study of Church History}

The relationship between Zionism and Pentecostalism in South Africa is an important study for church historians, specifically the Black Zionist roots in the AFM of South Africa. The Black Zionist roots in the AFM, through the lens of decoloniality, challenge church historians in South Africa to consider the contribution of Black people in shaping the foundation of Pentecostalism. Thus, the Black Zionist roots of the AFM are important for church historians as they contribute towards the future of Pentecostalism in general and the AFM in particular. It means that church historians, by ignoring the Black Zionist roots, will be doing so at their own peril. This study challenges church historians to look at studies like "Blackness and Pentecostalism" and "Pan Africanism and Pentecostalism." These studies will serve the purpose of decolonisation and Africanisation of the study of church history in a South African context.

\section{Conclusion}

Indeed, there is a strong link between Zionism and Pentecostalism in South Africa. In this article, the link is illustrated by the relationship between the Black Zionist movement and the AFM of South Africa. The link is so strong that the history of the AFM cannot be told without mentioning the Black Zionist movement. The article found 
that Wakkerstroom Congregation prepared the way for the ministry of John G Lake and Thomas Hezmalhalch to thrive in South Africa. Similarly, the duo held their first services at the Central Tabernacle in Zion in Bree Street until the establishment of the church. The main findings of this article are that most of the features of the Pentecostal movement practised in the AFM were also features of the Zionist movement in South Africa. The relationship between Zionism and Pentecostalism, as highlighted in this article, changes the way church historians in South Africa and elsewhere should study the origin of the AFM of South Africa. This means that church historians can no longer ignore the role played by Black people in South African Pentecostalism. Equally so, it challenges church historians in South Africa to incorporate Black Pentecostalism in their study of church history.

\section{References}

Anderson, Allan. 1991. Moya: The Holy Spirit in an African Context. Pretoria: University of South Africa.

Anderson, Allan. 1992. Bazalwane-African Pentecostals in South Africa. Pretoria: Unisa Press.

Anderson, Allan, and S. Otwang. 1993. TUMELO: The Faith of African Pentecostals in South Africa. Pretoria: University of South Africa.

Anderson, Allan. 1995. "Challenges and Prospects for Research into African Initiated Churches in Southern Africa." Missionalia: Southern African Journal of Mission Studies 23 (3): 283-294.

Anderson, Allan. 1996. “African Pentecostalism.” Studia Historiae Ecclesiasticae 22 (2): 114148.

Anderson, Allan. 1999a. "Dangerous Memories for South African Pentecostals." In Pentecostals after a Century: Global Perspectives on a Movement in Transition, 89-107, edited by A. H. Anderson and W. J. Hollenweger. Sheffield: Academic Press.

Anderson, Allan. 1999b. "The Lekganyanes and Prophecy in the Zion Christian Church." Journal of Religion in Africa 29 (3): 285-312. https://doi.org/10.1163/157006699X00368.

Anderson, Allan. 2000. Zion and Pentecost: The Spirituality and Experience of Pentecostal and Zionist/Apostolic Churches in South Africa. Pretoria. Unisa Press.

Anderson, Allan. 2001. "Types and Butterflies: African Initiated Churches and European Typologies.” International Bulletin of Missionary Research 25 (3): 107-113. ttps://doi.org/10.1177/239693930102500302.

Anderson, Allan. 2005. "New African Initiated Pentecostalism and Charismatics in South Africa." Journal of Religion in Africa 35 (1): 66-92. https://doi.org/10.1163/1570066052995843. 
Anderson, Allan. 2013. An Introduction to Pentecostalism. Cambridge: Cambridge University Press.

Burger, Isak. 1987. Die Geskiedenis van die Apostoliese Geloofsending van Suid-Afrika (19081958). Johannesburg: Evangelie Uitgewers.

Burger, Isak, and Marius Nel. 2008. The Fire Falls in Africa. Vereeniging: Christian Art.

Clark, Matthew. 2005. "Two Contrasting Models of Missions in South Africa: The Apostolic Faith Mission and the Assemblies of God.” Asian Journal of Pentecostal Studies 8 (1): $143-161$.

Daneel, Martinus L. 2004. "African Initiated Churches in Southern Africa: Protest Movements or Mission Churches?” In Christianity Reborn: The Global Expansion of Evangelicalism in the Twentieth Century, 181-218.

De Wet, Christiaan R. 1989. "The Apostolic Faith Mission in Africa, 1908-1980: A Case Study in Church Growth in a Segregated Society.” PhD thesis, University of Cape Town.

Dowie, J. A. (Ed.). 1904. "Zion among the Zulus in South Africa." Leaves of Healing 15: 853884. Zion City, Ill: Zion Publishing House. Accessed February 16, 2017.

http://www.iapsop.com/archive/materials/leaves_of_healing/leaves_of_healing_v15_1904 _apr-oct.pdf.

Erasmus, L. Johannes. 1996. "Theological Education in the Apostolic Faith Mission of South Africa." PhD thesis, University of South Africa.

Etherington, Norman. 1979. "The Historical Sociology of Independent Churches in South East Africa." Journal of Religion in Africa 10 (2): 108-126. https://doi.org/10.1163/157006679X00117.

Hadebe, Nontando M. 2017. "Commodification, Decolonisation and Theological Education in Africa: Renewed Challenges for African Theologians.” HTS Theological Studies 73 (3): 110. https://doi.org/10.4102/hts.v73i3.4550.

Horn, N. 1991. "Crossing Racial Borders in Southern Africa: A Lesson from History." Cyberjournal for Pentecostal-charismatic Research. http://www.pctii.org/cyberj/cyberj3/nico.html.

Hwata, Benny. 2005. "An Investigation of Different Phases of Pentecostal Experience in the Apostolic Faith Mission (AFM).” PhD thesis, University of South Africa.

Hollenweger, Walter J. 1972. The Pentecostals. SCM Press, London.

Kgatle, Mookgo S. 2016a. "The Influence of Azusa Street Revival in the Early Developments of the Apostolic Faith Mission of South Africa.” Missionalia 44 (3): 321-335. https://doi.org/10.7832/44-3-156. 
Kgatle, Mookgo S. 2016b. "Sociological and Theological Factors that Caused Schisms in the Apostolic Faith Mission of south Africa.” Studia Historiae Ecclesiasticae, 1-15. https://doi.org/10.17159/2412-4265/2016/1216.

Kgatle, Mookgo S. 2016c. "Servant Leadership in Mark 10: 35-45 Applied to African Pentecostal Christianity." PhD thesis, University of Pretoria.

Kgatle, Mookgo S. 2017. “A Socio-historical Analysis of the Sections in the Apostolic Faith Mission of South Africa from 1908 to the Present." Verbum et Ecclesia 38 (1): 1-10. https://doi.org/10.4102/ve.v38i1.1668.

Kgatle, Mookgo S. 2019. The Fourth Pentecostal Wave in South Africa: A Critical Engagement. Abingdon: Routledge. https://doi.org/10.4324/9780429343902.

Khathide, Agrippa G. 2010. Hamba Vangeli Elisha: A Portrait of Rev Job Y Chiliza-Pioneer of the African Gospel Church. Kempton Park: Acad SA.

Khorommbi, Ndwambi Lawrance. 2001. "Lutherans and Pentecostals in Mission amongst the Vhavenda: Comparative Study in Missionary Methods." Unpublished PhD Thesis, University of South Africa, Pretoria.

Le Roux, Pieter L. 1913. “The Central Tabernacle.” The Comforter Magazine, Oct.1913, 2.

Lindsay, Gordon. 1952. Sketches from the Life and Ministry of John G. Lake. Voice of Healing Publishing Company.

Lukhaimane, E. K. 1980. "The Zion Christian Church of Ignatius (Engenas) Lekganyane, 1924 to 1948: An African Experiment with Christianity." PhD thesis, University of the North.

Mashau, Thinandavha D. 2018. "Unshackling the Chains of Coloniality: Reimagining Decoloniality, Africanisation and Reformation for a Non-racial South Africa." HTS Theological Studies 74 (3): 1-8. https://doi.org/10.4102/hts.v74i3.4920.

Maxwell, David. 1999. "Historicizing Christian Independency: The Southern African Pentecostal Movement 1908 to 1960.” Journal of African History 40 (2): 243-264. https://doi.org/10.1017/S002185379800735X.

Mofokeng, Thabang. R. 2018. "Throwing the Baby out with the Bathwater: Cultural Reorientation of Black Pentecostalism in the Apostolic Faith Mission of South Africa, 1940-1975." PhD thesis.

Mofokeng, Thabang, and Mokhele Madise. 2019. "The Evangelicalisation of Black Pentecostalism in the AFM of SA (1940-1975): A Turning Point." Studia Historiae Ecclesiasticae 45 (1): 1-16. https://doi.org/10.25159/2412-4265/4050.

Moripe, S. 1996. “The Organisation and Management of the Zion Christian Church.” PhD thesis. 
Morton, Barry. 2012. “"The Devil Who Heals': Fraud and Falsification in the Evangelical Career of John G Lake, Missionary to South Africa 1908-1913." African Historical Review 44 (2): 98-118. https://doi.org/10.1080/17532523.2012.739752.

Morton, Barry. 2014. “"The Rebellion from Below” and the Origins of Early Zionist Christianity." African Historical Review 46 (2): 25-47. https://doi.org/10.1080/17532523.2014.943924.

Morton, Barry. 2017. "Elias Letwaba, the Apostolic Faith Mission, and the Spread of Black Pentecostalism in South Africa." Studia Historiae Ecclesiasticae 43 (2): 1-17. https://doi.org/10.25159/2412-4265/1333; https://doi.org/10.17159/2412-4265/2016/1333.

Naidoo, Marylin. 2016. "Overcoming Alienation in Africanising Theological Education.” HTS Teologiese Studies/Theological Studies 72 (1). https://doi.org/10.4102/hts.v72i1.3062.

Nel, Marius. 2005. "P. L. le Roux, Dutch Reformed Missionary, Zionist Preacher and Leader of the Apostolic Faith Mission of South Africa, and the Origin of some of the African Independent Churches in Southern Africa." Dutch Reformed Theological Journal/Nederduitse Gereformeerde Teologiese Tydskrif 46 (1-2): 200-208.

Nel, Marius. 2020. The Prosperity Gospel in Africa: An African Pentecostal Hermeneutical Consideration. Wipf and Stock Publishers.

Oosthuizen, Gerhardus Cornelis. 2000. "The African Independent Churches in South Africa: A History of Persecution.” Emory Int'l L. Rev., no. 14: 1089.

Ndlovu-Gatsheni, Sabelo J. 2017. "The Emergence and Trajectories of Struggles for an 'African University': The Case of Unfinished Business of African Epistemic Decolonisation.” Kronos 43 (1): 51-77. https://doi.org/10.17159/2309-9585/2017/v43a4.

Nicol, John. T. 1966. The Pentecostals (Pentecostalism). Plainfield, New Jersey: Logos International.

Poewe, Karla O. 1988. "Links and Parallels between Black and White Charismatic Churches in South Africa and the States: Potential for Cultural Transformation." Pneuma 10 (2): 141158. https://doi.org/10.1163/157007488X00091.

Ramantswana, Hulisani. 2016. "Decolonising Biblical Hermeneutics in the (South) African Context." Acta Theologica, no. 36: 178-203.

Ramantswana, Hulisani. 2019. "Prophets Praying for, or Preying on People’s Faith: A Reflection on Prophetic Ministry in the South African Context." In die Skriflig/In Luce Verbi 53 (4): 1-8. https://doi.org/10.4102/ids.v53i4.2495.

Ranger, Terence. 2007. “African Initiated Churches.” Transformation 24 (2): 65-71. https://doi.org/10.1177/026537880702400201. 
Reddy, Dean C. 1992. "The Apostolic Faith Mission of South Africa with Special Reference to its Rise and Development in the 'Indian' Community." PhD thesis, University of KwaZulu-Natal.

Resane, Kelebogile T. 2018. "Pentecostals and Apartheid: Has the Wheel Turned around since 1994?” In die Skriflig 52 (1): 1-8. https://doi.org/10.4102/ids.v52i1.2324.

Richardson, Leopold K. 2013. "What has Pentecostalism to do with Race Relations? A Study of the Apostolic Faith Mission in South Africa? "School of Divinity, Regent University.

Roy, Kevin. 2000. Zion City RSA: The Story of the Church in South Africa. Pretoria: South African Baptist Historical Society.

Sakupapa, Teddy. C. 2018. "The Decolonising Content of African Theology and the Decolonisation of African Theology-Reflections on a Decolonial Future for African Theology." Missionalia 46 (3): 406-424. https://doi.org/10.7832/46-3-277.

Sundkler, Bengt. 1961. Bantu Prophets in South Africa. London: Oxford University Press.

Sundkler, Bengt. 1976. Zulu Zion and some Swazi Zionists. London: Oxford University Press.

Tshaka, Rothney S. 2015. "The Black Church as the Womb of Black Liberation Theology? Why the Uniting Reformed Church in Southern Africa (URCSA) is not a Genuine Black Church?" HTS Teologiese Studies/Theological Studies, no. 71 (3). https://doi.org/10.4102/hts.v71i3.2800.

West, Martin. 1975. Bishops and Prophets in a Black City: African Indépendant Churches in Soweto. Johannesburg, Cape Town: David Philip. 